\title{
Influence of the Angle of Incident Light on the Performance of Textured Silicon Solar Cells
}

\author{
J. Gulomov*, R. Aliev ${ }^{\dagger}$ \\ Andijan State University, 129, Universitet St., 170100 Andijan, Uzbekistan
}

(Received 02 November 2021; revised manuscript received 18 December 2021; published online 20 December 2021)

\begin{abstract}
It is important to study environmental effects on the properties of solar cells because solar cells are usually used in open environments. If the surface morphology of a solar cell changes, the angle of incident light will change depending on its photoelectric properties. So, in this paper, the photoelectric properties of silicon solar cells covered with upright pyramids with different base angles were investigated depending on the angle of incident light. From the obtained results, it was found that when the angle of incident light is varied from $0^{\circ}$ to $80^{\circ}$, the short circuit current densities of planar and pyramidal textured silicon solar cells with base angles of pyramids of $50.4^{\circ}$ and $70.4^{\circ}$ decrease to $82.6,88.8,89.8 \%$, the open circuit voltages decrease to $10.5,12.8,14.1 \%$ and the fill factors decrease to $1.9,2.2$ and $3.2 \%$. The efficiency of a silicon solar cell covered with pyramids with a base angle of $70.4^{\circ}$ is better than those of planar and other textured silicon solar cells in the range of incident light angles from $0^{\circ}$ to $80^{\circ}$, although the dependence of its photoelectric parameters on the angle of incident light increases.
\end{abstract}

Keywords: Solar cell, Silicon, Simulation, Angle of incident light, Pyramid, Texture.

\section{INTRODUCTION}

Nowadays, the reserves of natural resources are decreasing, so the people's demand for energy is increasing. Thus, the use of renewable energy resources is increasing [1]. There are a lot of types of renewable energy. Solar energy is most commonly used. In particular, solar energy is converted into heat energy and electric energy. Solar cells convert light energy to electrical energy [2]. There are a lot of types of solar cells. Many solar cells with high efficiency are produced in laboratory. But silicon solar cells (SSCs) are solar cells which are produced industrially. So, in this paper, SSCs are chosen as an object of research. According to theoretical calculations, efficiency of SSCs does not exceed $29 \%$ [3]. But efficiency of a monocrystalline SSC, which is produced in industry, is $24.58 \%$ [4]. Efficiency of SSCs was increased to $26 \%$ by Zunke Lui with digital modeling [5]. Optical and electrical properties of SSCs should be improved in order to increase their efficiency [6]. Various textures are formed on the surface of solar elements, and the surface of solar cells is covered with optical layers [7]. In addition, if $\mathrm{Pt}$ nanoparticles are introduced into SSCs, the optical [8] and electrical [9] properties of SSCs are improved, and the efficiency of SSCs is doubled. Moreover, the effect of the environment on the photoelectric parameters of SSCs has been studied properly [10].

In experiments, textures are formed on the surface of SSCs by chemical etching, i.e., alkali or acid. Alkali is used to form regular pyramids; HF acid solution is used to form irregular pyramids [11].

Nowadays, the angle of the base of pyramids formed on the surface of SSCs is $54^{\circ}$ since the crystal orientation of the silicon surface is (111) [12]. In our previous research, the highest efficiency was observed when the $\mathrm{ABP}$ (angle of the base of the pyramid) was $70.4^{\circ}$. So, in this research, a PSSC (planar silicon solar cell), a $54^{\circ}$ PTSSC (silicon solar cell covered with a pyramidal texture with an $\mathrm{ABP}$ of $54^{\circ}$ ) and a $70.4^{\circ}$-PTSSC (silicon solar cell covered with a pyramidal texture with an $\mathrm{ABP}$ of $70.4^{\circ}$ ) are chosen as a research object. In this paper, periodic pyramidal textures are formed on the surface of SSCs because when the Zheng Fang chemical feds the silicon surface with alkali $\mathrm{NaOH}$ during $456 \mathrm{~s}$, textures of the same size are formed on the surface of silicon [13].

AOI (angle of incident light) changes during the day. Virtually textures are formed on the surface of the entire solar cell. So, in this paper, the effect of AOI on the photoelectric properties of textured SSCs is studied. Because, if $\mathrm{ABP}$ of the texture changes, the effect of AOI should change. The optimal option of ABP of the texture, which was formed on the surface of SSCs, can be found for a specific zone.

\section{METHOD}

Three kinds of methods used for SSCs are investigated: experiment, theory and modeling. We studied the effect of AOI on the photoelectric properties of textured SSCs in this article by modeling. In the modeling, Sentaurus TCAD (technology computing aided design) by Synopsys was used.

Regular pyramidal textures were formed on the surface of SSCs. There is symmetry in solar elements, so a 2D model was used for the calculation. In Fig. 1, a 2D view of the pyramid is shown, its ABP is explained with $a=2 h / w$.

\footnotetext{
* jasurbekgulomov@yahoo.com

† alievuz@yahoo.com
} 


\subsection{Geometric Model}

The Sentaurus Structure Editor tool of Sentaurus TCAD was used to create a geometric model of semiconductor devices. Fig. 2 shows three types of SSCs: PSSC (a), 54․-PTSSC (b) and 70.4 ${ }^{\circ}$-PTSSC (c).

An algorithm was produced by Tool Command Language (TCL) in order to form planar and textured solar cells by only one project (Appendix 1). The width of the pyramids was taken equal to $1 \mu \mathrm{m}$ in order to form regular pyramids with various $\mathrm{ABP}$ on the surface of SSCs. ABP was changed by changing the height of the pyramids. So, if the height of the pyramid is $h=0$, the appearance of a SSC will be planar.

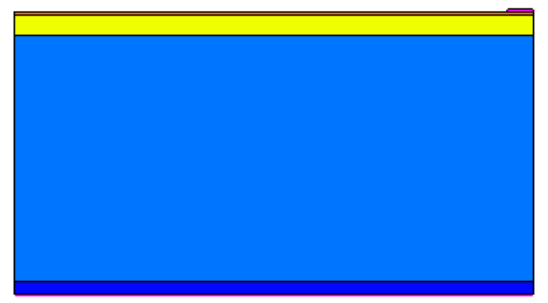

a

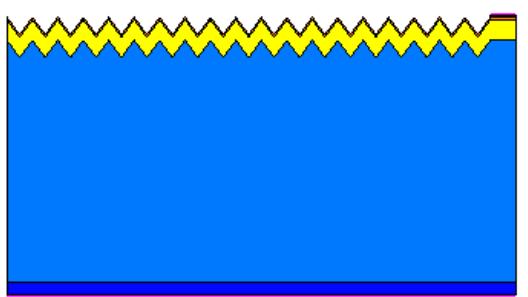

$\mathrm{b}$

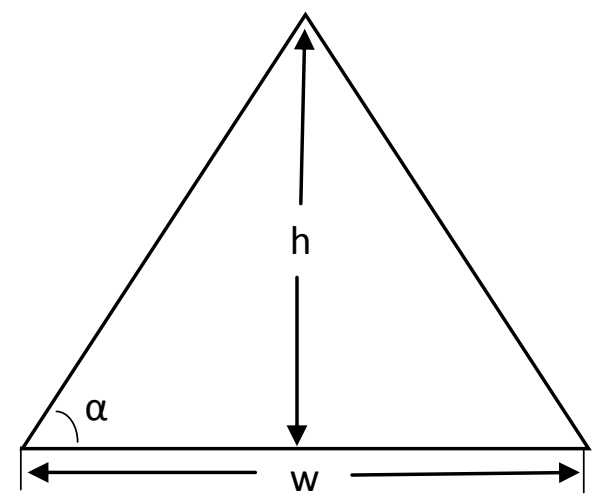

Fig. $1-2 \mathrm{D}$ appearance of a pyramid: $a-\mathrm{ABP}, h-$ height, and $w-$ width

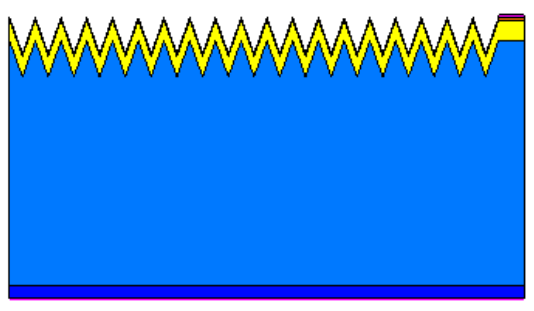

c

Doping concentration, $\mathrm{cm}^{-3}$

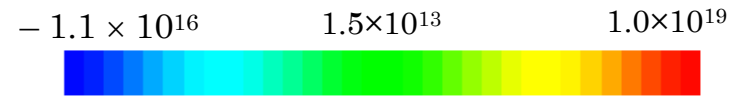

Fig. 2 - Geometric model of the SSC which was formed in SDE: a - PSSC, b - 54 $4^{\circ}$ PTSSC, c - 70.4 ${ }^{\circ}$-PTSSC

\subsection{Theory}

A geometric model, which was produced by Sentaurus Structure Editor, simulates physical properties by Sentaurus Device. The simplest state of a semiconductor device is the equilibrium state. In this state, the concentration of charge carriers is determined by Fermi statistics, then Poisson equation is used to calculate the electrical properties of the device. The equilibrium state does not occur in reality because it is not an ideal state. If a semiconductor device is illuminated, heated or placed in an external electric field, motion of electrons and holes occurs. The dependence of the photocurrent on the charge carrier concentration is determined by using the continuity equation. There are various forms of the continuity equation: drift diffusion, thermodynamic, hydrodynamic, and Monte Carlo [14]. The most common and simplest of them is the drift diffusion model. So, in this paper, the drift diffusion model, which is given by equations (1) and (2), is used to calculate the carrier transport:

$$
\begin{gathered}
\nabla \cdot \vec{J}_{n}=q R_{n e t, n}+q \frac{\partial n}{\partial t} \\
-\nabla \cdot \vec{J}_{p}=q R_{n e t, p}+q \frac{\partial p}{\partial t}
\end{gathered}
$$

where $J_{n}$ and $J_{p}$ are the current densities of electrons and holes, $R_{\text {net, }, p}$ and $R_{\text {net, } n}$ are the net recombination of electrons and holes, $t$ is the time, $q$ is the charge, $n$ and $p$ are the electron and hole concentrations.

There are a lot of methods to determine the optical properties of SSCs. The most common of them are the transfer matrix method (TMM), ray tracing and beam propagation. In this paper, the ray tracing method is used because when texture is formed on the surface of SSCs, light rays refract several times between two pyramids. Population of light is taken into account in the ray tracing method. So, when light falls at the interface between two media, rays are divided into refracted and reflected. In this paper, the minimum intensity is taken as $10^{-5} \mathrm{~W} / \mathrm{m}^{2}$. So, if the intensity of a light ray is less than $10^{-5} \mathrm{~W} / \mathrm{m}^{2}$, the calculation for this ray stops. At the interface between two media, angles of the refracted and reflected rays are identified by Snell's law, and the intensity distributions are determined by Fresnel's law. Light absorption is calculated by Burger Lambert's law. So, the use of the laws of Snell, Fresnel and Burger-Lambert is enough to determine the optical properties of SSCs. But, according to their combined application, various methods are formed.

In this paper, the AM1.5G spectrum is chosen as a source of light incident on SSCs.

\section{RESULTS AND DISCUSSION}

Various textures were formed on the surface of SSCs in order to absorb more rays in the volume of solar cells. According to our theoretical research, a ray which falls between two pyramids can be refracted 4 times at $\mathrm{ABP}$ of $80^{\circ}>a>64^{\circ}$. When we relied only on optical calculations, the maximum absorption coefficient was observed for $73.12^{\circ}$-PTSSC. But, if the surface of SSCs enlarges, the recombination rate also in- 
creases. So, the optical, thermal and electric properties of SSCs are taken into account in the Sentaurus TCAD. Therefore, the maximum power conversion efficiency was observed in $70.4^{\circ}$-PTSSC. If ABP increases, both the absorption coefficient and the surface recombination rate also increase. Then, the efficiency of SSCs was improved 1.6 times by creating textures with an ABP of $70.4^{\circ}$. In the experiment, when the surface of SSCs was chemically treated with $\mathrm{NaOH}$ or $\mathrm{KOH}$, regular pyramids with an ABP of $54.74^{\circ}$ formed on the surface of SSCs [15]. Moreover, the efficiency was improved 1.33 times compared to simple PSSC [15].

When AOI changes, the SSC absorption coefficient changes. Besides, when textures are formed on the surface of SSCs, the dependences of ABP, geometric size, and photoelectric parameters on AOI change accordingly. Fig. 3 shows the distribution of the absorbed photon concentration through the volume of PSSC (a), $54^{\circ}$-PTSSC (b) and $70.4^{\circ}$-PTSSC at an AOI of $0^{\circ}(1)$ and $50^{\circ}$ (2). In Fig. 3.1, the shortest absorption depth was identified in (c). Because, when texture is formed on the surface of SSCs, its reflection coefficient decreases. In the Saleem Zaidi's experiment, the light reflection coefficient is $43 \%$ for PSSC, and for PTSSC it is smaller than $3 \%$ [17]. Besides, in Fig. 3.2, when AOI was 50, the absorbed photon concentration improved than with perpendicular illuminated. In addition to a decrease in the absorption depth, the light absorption coefficient decreased, as in the experimental studies of Hsiao-Yen Chung [18].

When AOI changes, so does the intensity of the absorbed light in SSCs. The short circuit current of SSCs is very sensitive to changes in the light intensity. In Fig. 4, the dependences of the short circuit current of PSSC (1), 54 $4^{\circ}$-PTSSC (2) and $70.4^{\circ}$-PTSSC (3) on AOI are shown. When AOI changes from $0^{\circ}$ to $80^{\circ}$, the short circuit current decreases to $82.6 \%$ for PSSC, to $88.78 \%$ for $54^{\circ}$-PTSSC, and to $89.8 \%$ for $70.4^{\circ}$-PTSSC. When AOI changes from $0^{\circ}$ to $80^{\circ}$, a decrease in the short circuit current of $52^{\circ}$-PTSSC to $83.8 \%$ is identified by using the module of SunSolve of Mandy Lewis "SMARTS" program [19].
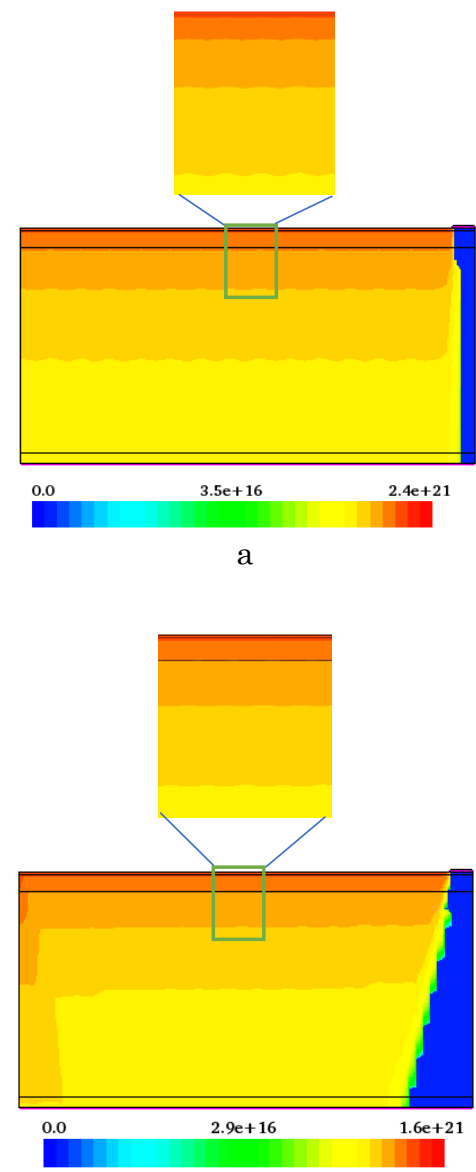

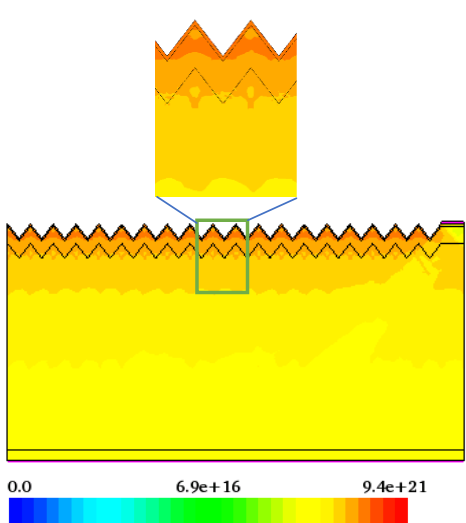

$\mathrm{b}$

1

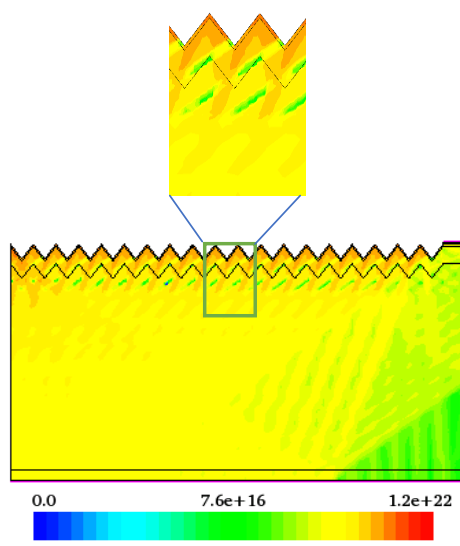

$\mathrm{b}$

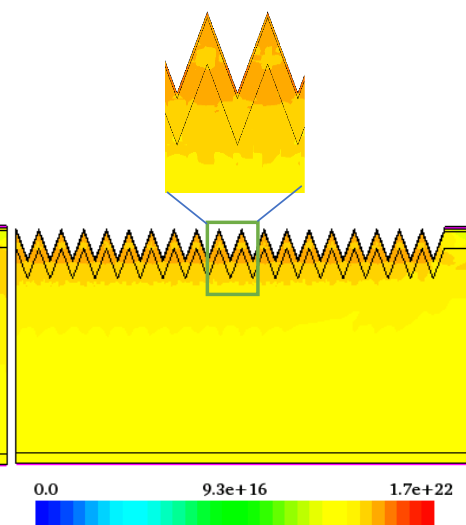

c

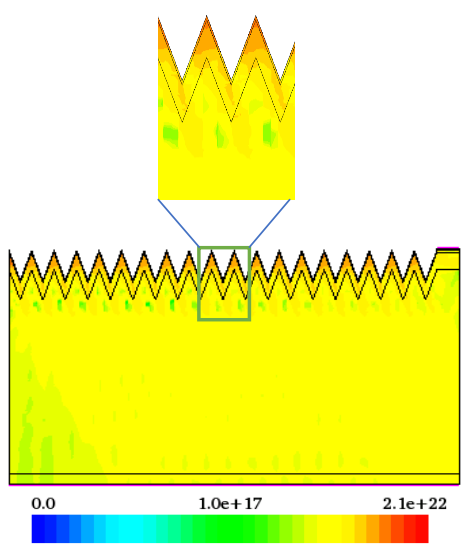

C

Fig. 3 - Distribution of the absorbed photon concentration through the volume of PSSC 


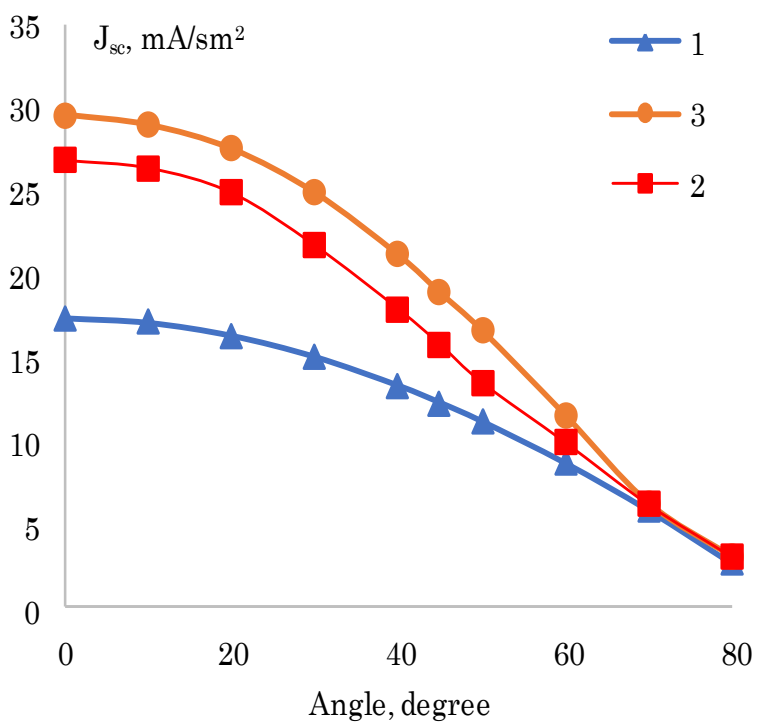

Fig. 4 - Dependences of the short circuit current on AOI for PSSC (1), 54 $4^{\circ}$-PTSSC (2) and 70.4 ${ }^{\circ}$-PTSSC (3)

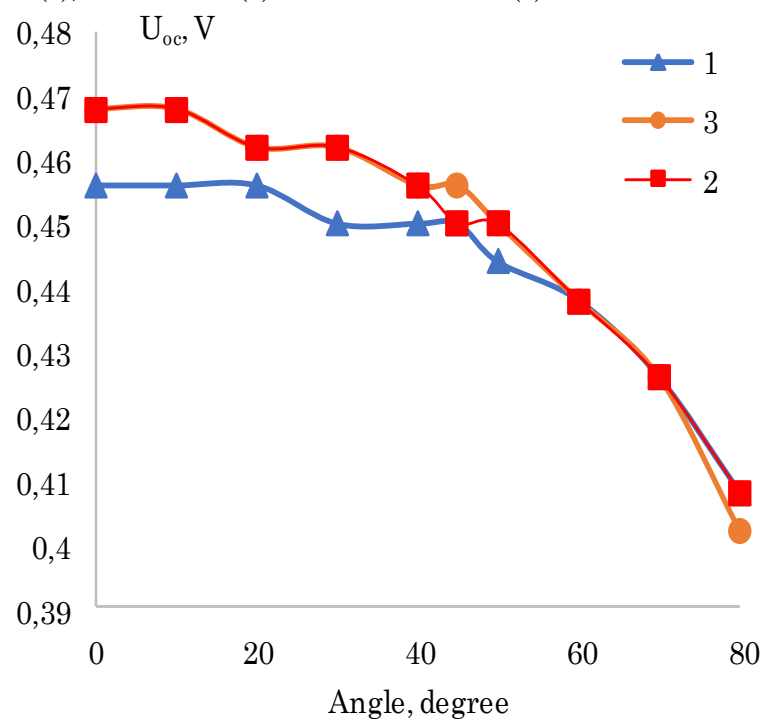

Fig. 5 - Dependences of the open circuit voltage on AOI for PSSC (1), $54^{\circ}$-PTSSC (2) and $70.4^{\circ}$-PTSSC (3)

When the absorbed light intensity changes, the concentration of photogenerated carriers also changes. A change in the carrier concentration causes a change in the band gap of silicon. The open circuit voltage of SSCs depends on the band gap of silicon. Fig. 5 shows the dependences of the open circuit voltage on AOI for

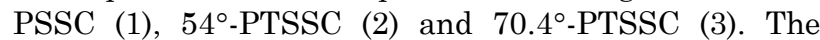
open circuit voltage of $54^{\circ}$-PTSSC (2) and $70.4^{\circ}$-PTSSC (3) is almost the same. But the open circuit voltage differs by $0.006 \mathrm{~V}$ for an AOI of $45^{\circ}$ and $80^{\circ}$. The open circuit voltage of PSSC is $0.012 \mathrm{~V}$ less than that of PTSSC at an AOI of $0^{\circ}$. The open circuit voltage of PTSSC and PSSC changes the same when AOI changes from $60^{\circ}$ to $80^{\circ}$. When AOI changes from $0^{\circ}$ to $80^{\circ}$, the open circuit voltage decreases to $10.5 \%$ for PSSC, to $12.8 \%$ for $54^{\circ}$-PTSSC and to $14.1 \%$ for $70.4^{\circ}$-PTSSC. When AOI changes from $0^{\circ}$ to $45^{\circ}$, the open circuit voltage drops to $1.6 \%$, according to the TCAD modeling results of Serra Altinoluks [20]. But, in this paper, the open circuit voltage of $54^{\circ}$-PTSSC decreases to $2.5 \%$.

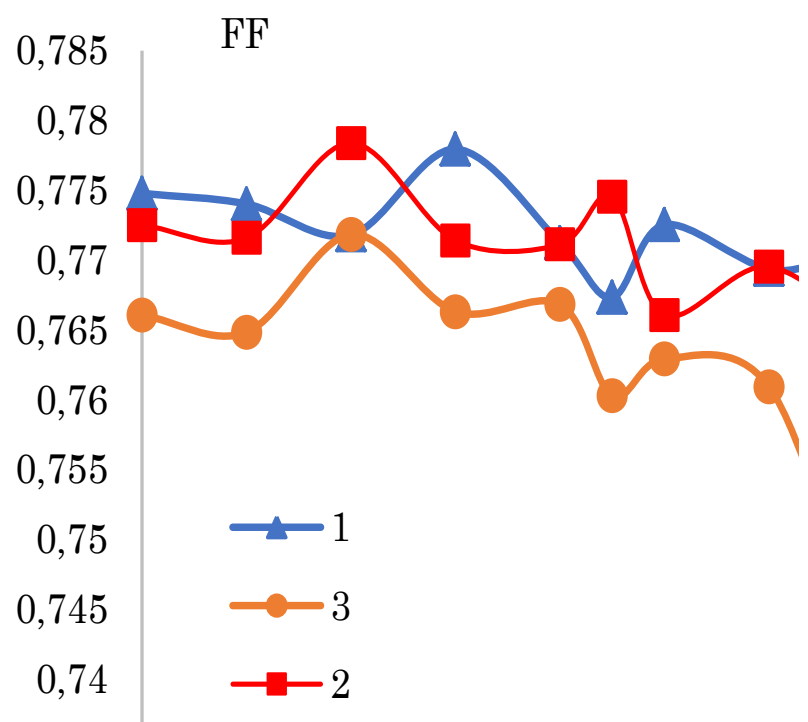

Fig. 6 - Dependence of the fill factor on AOI for PSSC (1), $54^{\circ}$-PTSSC (2) and $70.4^{\circ}$-PTSSC (3)

One of the main parameters of SSCs is the fill factor. In Fig. 6, the dependences of the fill factor on AOI of PSSC (1), 54 ${ }^{\circ}$-PTSSC (2) and $70.4^{\circ}$-PTSSC (3) are depicted. According to the results, it is identified that the fill factor of PSSC is better than that of PTSSC. Because if AOI increases, refraction of light between adjacent textures decreases. But the fill factor of $54^{\circ}$-PTSSC and $70.4^{\circ}$-PTSSC has a maximum value at an AOI of $20^{\circ}$. The same maximum value is observed for $54^{\circ}$-PTSSC at an AOI of $45^{\circ}$. The fill factor of PSSC and $54^{\circ}$-PTSSC is almost the same at an AOI of $80^{\circ}$, but the fill factor of $70.4^{\circ}$-PTSSC is less by $2 \%$. When AOI increases, photons are absorbed on the top of the pyramids of $70.4^{\circ}$-PTSSC. Therefore, the fill factor decreases. Besides, if $\mathrm{ABP}$ of the pyramid improves, so does its surface. Therefore, the surface recombination rate increases. Surface recombination affects the quality of SSCs. Thus, if ABP of the pyramid increases, the fill factor of the SSC decreases.

\section{CONCLUSIONS}

The effect of AOI on the photoelectric properties of SSCs has been comprehensively studied. According to $\mathrm{ABP}$ of textures formed on the surface of SSCs, the dependence of their photoelectric parameters on AOI changes. In conclusion, at an AOI of $0^{\circ}$, the short circuit current and the open circuit voltage of $70.4^{\circ}$-PTSSC are higher than those of PSSC and $70.4^{\circ}$-PTSSC; if the value of AOI is $80^{\circ}$, they are almost equal. So, as AOI increases, the photoelectric parameters of $70.4^{\circ}$-PTSSC decrease faster than other designs. So, if the geometric structure of an SSC changes, its dependence of the photoelectric properties on AOI also changes. For this reason, when the geometric structure changes, the reflection, transmission and absorption coefficients of SSCs also change. According to the short circuit current and efficiency values, it is preferable that $70.4^{\circ}$-PTSSC be used in any continent of the world because the short circuit current and efficiency of $70.4^{\circ}$-PTSSC are better than those of other PTSSC at all $\mathrm{AOI}$ values. 


\section{REFERENCES}

1. P.A. Østergaard, N. Duic, Y. Noorollahi, S.A. Kalogirou, Renew. Energy 179, 877 (2021).

2. S. Mekhilef, R. Saidur, A. Safari, Renew. Sustain. Energy Rev. 15 No 4, 1777 (2011)

3. W. Shockley, H.J. Queisser, J. Appl. Phys. 32 No 3, 510 (1961).

4. D. Chen, Y. Chen, Z. Wang, J. Gong, Ch. Liu, Y. Zou, Y. He, Y. Wang, L. Yuan, W. Lin, R. Xia, L. Yin, X. Zhang, G. Xu, Y. Yang, H. Shen, Zh. Feng, P. Altermatt, J. Verlinden, Sol. Energy Mater. Sol. C. 206, 110258 (2020).

5. Z. Liu, Zh. Yang, W. Wang, Q. Yang, Q. Han, D. Ma, H. Cheng, Y. Lin, J. Zheng, W. Liu, M. Liao, H. Chen, Y. Wang, Y. Zeng, B. Yan, J. Ye, Sol. Energy 221, 1 (2021).

6. M. Sui, Y. Chu, R. Zhang, J. Phys. Conf. Ser. 1907 No 1, 012026 (2021).

7. V.V. Iyengar, B.K. Nayak, M.C. Gupta, Sol. Energy Mater. Sol. C. 94 No 12, 2251 (2010).

8. J. Gulomov, R. Aliev, A. Mirzaalimov, N. Mirzaalimov, J. Kakhkhorov, B. Rashidov, S. Temirov, Int. J. Renew. Energy Dev. 10 No 4, 731 (2021).

9. R. Aliev, J. Gulomov, M. Abduvohidov, S. Aliev, Z. Ziyoitdinov, N. Yuldasheva, Appl. Sol. Energy 56 No 5, 365 (2020).

10. J. Gulomov, R. Aliev, J. Nano- Electron. Phys. 13 No 4, 04033 (2021)

\section{APPENDIX 1}

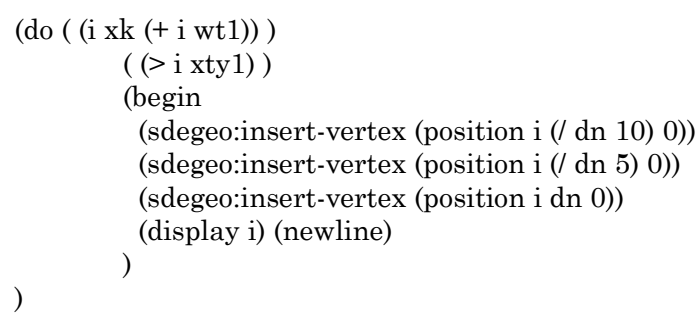

$($ do $(($ i xt01 (+ i wt)) )
11. K. Kim, S.K. Dhungel, S. Jung, D. Mangalaraj, J. Yi, Sol. Energy Mater. Sol. C. 92 No 8, 960 (2008).

12. R.E. Oosterbroek, J.W. Berenschot, H.V. Jansen, A.J. Nijdam, G. Pandraud, A. van den Berg, M.C. Elwenspoek, J. Microelectromechan. Syst. 9 No 3, 390 (2000).

13. Z. Fang, Z. Xu, D. Wang, S. Huang, H. Li, J. Mater. Sci.: Mater. Electron. 31 No 8, 6295 (2020).

14. C.C. McAndrew, E.L. Heasell, K. Singhal, Semicond. Sci. Technol. 2 No 10, 643 (1987).

15. Z. Mrazkova, I. Sobkowicz, M. Foldyna, K. Postava, I. Florea, J. Pištora, P. Cabarrocas, Prog. Photovolt.: Res. Appl. 26 No 6, 369 (2018)

16. F.C. Marques, J. Urdanivia, I. Chambouleyron, Sol. Energy Mater. Sol. C. 52 No 3, 285 (1998).

17. S.H. Zaidi, D.S. Ruby, J.M. Gee, IEEE Trans. Electron Dev. 48 No 6, 1200 (2001).

18. H.-Y. Chung, C.-H. Chen, H.-S. Chu, Int. J. Photoenergy 2008, 1 (2008).

19. M. Lewis, E. Tonita, Ch. Valdivia, R. Obhi, J. Leslie, M. Bertoni, K. Hinzer, Conference Record of the IEEE Photovoltaic Specialists Conference, 191 (Chicago, IL, USA: 2019).

20. S. Altinoluk, N. Kumar, E.H. Ciftpinar, O. Demircioglu, R. Turan, D. Vasileska, Global Challenges 4 No 9, 1900105 (2020).

\title{
Вплив кута падіння світла на характеристики текстурованих кремнієвих сонячних елементів
}

\author{
J. Gulomov, R. Aliev \\ Andijan State University, 129, Universitet St., 170100 Andijan, Uzbekistan
}

\begin{abstract}
Важливо знати вплив навколишнього середовища на властивості сонячних елементів, оскільки вони зазвичай використовуються у відкритих середовищах. Якщо морфологія поверхні сонячного елемента змінюеться, кут падіння світла буде змінюватися залежно від його фотоелектричних властивостей. Отже, у роботі досліджувалися фотоелектричні властивості кремнієвих сонячних елементів, покритих вертикальними пірамідами з різними кутами основи, залежно від кута падіння світла. 3 отриманих результатів було виявлено, що при зміні кута падіння світла від $0^{\circ}$ до $80^{\circ}$ густини струму короткого замикання площинних, пірамідальних і текстурованих кремніевих сонячних елементів з кутами основи пірамід $50.4^{\circ}$ i $70.4^{\circ}$ зменшуються до 82,$6 ; 88,8 ; 89,8 \%$, напруги холостого ходу зменшуються до 10,$5 ; 12,8 ; 14,1 \%$, а коефіціенти заповнення зменшуються до 1,9; 2,2 та 3 \%. ККД кремніевого сонячного елемента, покритого пірамідами з кутом основи $70.4^{\circ}$, краще, ніж ККД планарних та інших текстурованих кремніевих сонячних елементів в діапазоні кутів падіння світла від $0^{\circ}$ до $80^{\circ}$, хоча залежність його фотоелектричних параметрів від кута падаючого світла зростае.
\end{abstract}

Ключові слова: Сонячний елемент, Кремній, Моделювання, Кут падіння світла, Піраміда, Текстура. 